\title{
THE USE OF ACTIVE AND PASSIVE SENTENCES ON STUDENTS' WRITING RECOUNT TEXTS
}

\author{
Siswanto \\ Education Program, Postgraduate Faculty \\ Universitas Indpraprasta PGRI \\ e-mail: $\underline{\text { siswanto.samuel.ss@gmail.com }}$
}

\begin{abstract}
Learning writing skills used the eleventh-grade students of SMK Tunas Harapan, Jelambar, Petamburan. In conducting this research, it is qualitative research using a survey method. Data were collected by population and sample observation, interview, a document study, data of the students. The research of evaluation of the active and passive sentences, the result of the students' error are the total error in using active sentences are 171 errors that consist of 34 errors or $19,88 \%$ error of misinformation, 92 errors or $53,88 \%$ error of omission, 43 errors or $25,14 \%$ error of addition, two errors or $1,66 \%$ error of misordering. The result of the students' error are: the total error in using Passive sentences are 17 errors that consist of 5 errors or 29, $41 \%$ error of misinformation, six errors or $35,29 \%$ error of omission, six errors or $35,29 \%$ error of addition, 0 errors or $0 \%$ error of misordering, the process of teaching and learning Writing using Recount Text of the Active and Passive Sentences are effective and able to implement as an alternative way in teaching and learning process
\end{abstract}

Keywords: active and passive sentences, students' writing, recount text.

\section{Introduction}

This research exclusively focuses on active and passive sentences, the active and passive sentences to know on students' writing recount text. The first one is to describe the active sentences. The second is about the passive sentences. The third is about writing. The fourth is about the recount text. The active and passive sentences are to use the students on writing and say something about recount text. Every student must learn the active and passive sentences well to refer to the correct writing on recount text. Language is an integral part of communication. It serves as a conduit for people to communicate what they are thinking. They pose questions, share their feelings, opinions, and emotions, and express themselves verbally.

To communicate with people worldwide, the requirement is not only for oral communication abilities, but also for written proficiency. Written mass media are the most influential parts of our life today. Moreover, the existence of the internet enables worldwide connections for people worldwide to communicate, get, and give the recent information in all aspects of lives, which emerges a great demand of having writing ability in English. Thus, in order to communicate with people worldwide, not only oral communication skills are needed, but also written proficiency. The internet enables people worldwide to interact, obtain, and distribute current knowledge.

The active and passive sentences are imperative in this lesson because not all students can understand well, particularly for Private Vocational high school English. To improve our English bits of knowledge, not only always read the text, speak, or take a conversation but write the text is essential, especially for students to improve their English skills. In this context, to develop in English, we can learn English by writing the text. The active and passive sentences in writing are essential because the writing of the sentences to know and remember what we will talk about our experiences that we had done in the 


\section{INFERENCE: Journal of English Language Teaching}

Vol. 4, No. 1, April - July 2021

p-ISSN: 2615-8671

e-ISSN: 2615-868X

past. For many people who practice English, one of the ways is using the writing way. This way is significant because the advantage is to sharpen and develop foreign language writing skills.

On the other side, we do not only sharpen the writing but also to know and sharpen English grammar correctly. The active and passive sentences in writing the text in English can also make the feel of meaning and create each word to the sentence's faster knowledge of English. The way can also make our skill faster to know English correctly because in writing the text we know the false and the correct in each word. It can also increase our sharpen of thinking to be good in English writing. Writing also has a good potential to give information to other people and increase many abilities to our writing skill. By writing, we can also apply the foreign language, grammar, and vocabulary by thinking of words.

Active and passive sentences are in writing not only for communicating but also for expressing our idea or thinking to create many words. Expressing is not only using a speech or talking but also expressing with someone by writing the text on the paper, note, email, and letter. To communicate with someone is also the same way; we can create our expressing by writing the text into good communication. These statements of communicating and expressing to other people by writing are simple ways for communication. In other words, the use of active and passive sentences are in writing not only for communicating but also for expressing our idea or thinking. Expressing is not only using a speech or talking but also expressing with someone by writing the text on the paper.

In this context of active and passive sentences on students' writing recount text, we will learn some active sentences and passive sentences. The learners must understand well the writing of communication of an active sentence and passive sentence. The active sentence is the subject acts as the verb, while the passive sentence is the subject of the sentence has an action done to it by someone or something else. The writer of active and passive sentences must be careful of writing into good communication to the other people. If our interlocutors smarter or understand well than us to communicate, it makes us lousy knowledge in front of them. Regarding the focus of the research above, the problem in this research needs to be formulated as follows:

1. How to use the active and the passive sentences in writing the text?

2. How is the use written in writing on students' recount text?

\section{Method}

The writer chose The Private Vocational High School of Tunas Harapan Petamburan in West Jakarta as a research object to learn English teaching methods of the simple ability or skill. The writer wants to know the students' abilities and skills of their English. They taught English and the process in a classroom between teacher and students how to learn English in Private vocational High School. At the beginning of the research, the researcher observed to determine the respondents who would be taken from the student. After deciding the sampling, ten, the writer starts to research out that the material is studied in that population. The writer researched at around six months starting in August 2019 to January 2020.

The writer employs qualitative research and the descriptive method. This study is action research in nature. It was not merely about searching for a conclusive way to learn why we do a thing but instead finding an answer about how we could do things better. It dealt with how to invent a better way of teaching for the student's benefits. This classroom action research was done to find the best way to use active and passive sentences in writing on students' recount text of the Vocational High school students at eleventh Grade in West Jakarta.

The writer took sources of data. The population of this research is all the eleventh students of SMK Tunas Harapan in different majors: Administration and Accounting program, Jelambar, Petamburan, West Jakarta. Productive subject teacher, English teacher, learners, principal, interview, observation, and test result from teachers' and document. Furthermore, the documents of administration from the teacher connected to the subject that the writer took for data and the result of the process. In this research, the writer used purposive sampling to take participants. Purposive sampling is one technique to make a sample based on a particular purpose of the researcher to take the sample for analysis.

The writer did some ways to collect data as follows: joining the class action to see the atmosphere of speaking class and to be interacting of the students motivate, collecting the related documents from the teacher, interviewing the learners, headmaster, English teachers and stake holders as one of the school elements that has been considered to be interviewed. 


\section{Results and Discussion}

After Analyzing the data, the writer found the total errors are 188 errors made by students in writing recount text Of Active Sentences, which consist of 92 errors of Omission, 43 errors of addition, 34 errors of misinformation, and two errors of misinformation misordering, for the Passive sentence which consist of 6 errors of Omission, 5 of Misinformation, 6 of Addition, the use of Active and passive sentences in writing recount text - analyzing for the qualities on student's writing recount text. Total items are 80 Samples of the use of active and passive sentences.

The writer found that eight students are outstanding, 27 students are good, 45 students are adequate, and students are deficient in writing active and passive sentences. Table 1 and Table 2 below show the percentage and the number of common type errors using active and passive sentences on students' writing recount text.

Table 1 Type the error of using active sentences of students' writing recount text

\begin{tabular}{|c|c|c|c|c|c|c|c|c|}
\hline \multirow{3}{*}{ Category } & \multicolumn{7}{|c|}{ Type of Errors } \\
\cline { 2 - 9 } & Misinformation & \multicolumn{2}{|c|}{ Omission } & \multicolumn{2}{c|}{ Addition } & Misordering \\
\cline { 2 - 9 } & Total & $\%$ & Total & $\%$ & Total & $\%$ & Total & $\%$ \\
\hline $\begin{array}{c}\text { Active } \\
\text { Sentences }\end{array}$ & 34 & 19,88 & 92 & 53,80 & 43 & 25,14 & 2 & 1,16 \\
\hline
\end{tabular}

From Table 1, it can be seen that the error of the use of active sentences on students' writing recount text shown that the lowest error is in the error of Misordering, there are 2or 1,44\%. Moreover, the highest is in the error of Omission. There are 92 or 53, 80\%. It can be concluded that almost all students made errors in Omission of the use of active sentences. Only a few of the students made errors in Misordering, Misinformation, and Addition of active sentences.

Table 2 Type the error of the use of passive sentences on students' writing recount text

\begin{tabular}{|c|c|c|c|c|c|c|c|c|}
\hline \multirow{2}{*}{ Category } & \multicolumn{7}{|c|}{ Type of Errors } \\
\cline { 2 - 9 } & Misinformation & \multicolumn{2}{|c|}{ Omission } & \multicolumn{2}{|c|}{ Addition } & \multicolumn{2}{|c|}{ Misordering } \\
\cline { 2 - 9 } & Total & $\%$ & Total & $\%$ & Total & $\%$ & Total & $\%$ \\
\hline $\begin{array}{c}\text { Passive } \\
\text { Sentence }\end{array}$ & 5 & 29,41 & 6 & 35,29 & 6 & 35,29 & 0 & 0 \\
\hline
\end{tabular}

From Table 2, it can be seen that the error of the use of Passive sentences on students' writing recount text shown that the lowest error is in the error of Misordering, there are 0 or $0 \%$. Furthermore, the highest is in the error of Omission and Addition there are 6 or 35,29\%. It can be concluded that almost all students made the errors in Omission and Addition of the use Passive sentences; no students made the error in Misordering.

Based on the data above, it can be concluded that a few students have outstanding quality in stating the writing recount text. More than half of the students have good quality in stating the writing recount text. Then, many students have poor quality in writing recount text. Comparing the frequency of the type of error of the use of active and passive sentences on students' writing recount text classifies the chart below: 


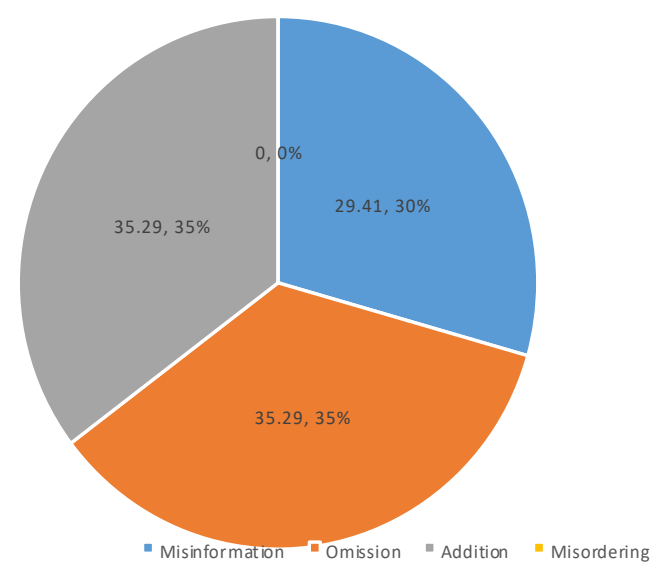

Figure 1 The Error of the Use Active Sentences of Students in Writing Recount Text

The research data are collected from the documentation of students' writing recount text made by SMK Tunas Harapan, Jelambar, Petamburan West Jakarta. As stated in the previous chapter, the writer wants to investigate whether active and passive sentences on students' writing recount text are classified into a group: misinformation, omission, addition, and misordering error. Besides, to classifies into four qualities are Very Good, Good, Adequate, and Poor.

The use of active and passive sentences in students' writing recounts text. There found some errors in part the active and passive sentences in writing recount text. There are many types of errors, omission, addition, misinformation, and misordering. The result of classification was calculated by frequency and percentage of each error.

The writer found the total of errors are 188 errors of active and passive sentences, which consist of, (1) the lowest is two errors of misordering or $1,66 \%$, (2) there are 49 errors of addition of $26,06 \%$, (3) there are 39nerrors of misinformation or 20,74\%, (4) the highest errors are 98 errors of Omission or 52, $13 \%$. Misinformation is the highest one of errors faces by the students in writing recount text. The kind of misinformation was overgeneralization: (1) Regular past verb, (2) Irregular verbs, (3) Past form modals, (4) verb after modal, (5) using be, was, were (6) time signal the most students make a mistake or forget to change the verb into a past verb. Based on the research, the students are still confused in writing and using the simple past tense of the verb.

Omission, the second error made by students, is the omission in writing recount text. The omission errors were found; (1) omission of the verb was a regular verb, irregular verb, after infinitives. (2) Regular past of using -ed and -d. (3) using of was, were. The omission happened because the students cannot perform well in writing the sentences and do not understand the rules in making the sentences of recount text. In addition, addition is the third error of the students in writing recount text. There are some errors found in addition; (1) Addition in the verb of the sentences. (2) Verb, their error appears because they are still confused when they have to use past tense in writing the recount text.

Misordering is the lowest number of errors of the students in writing recount text. There are three kinds of errors; (1) Subject-verb order, (2) verb-object, (3) was, were. The errors happened because the students still do not understand the rule of the tenses and structure. 


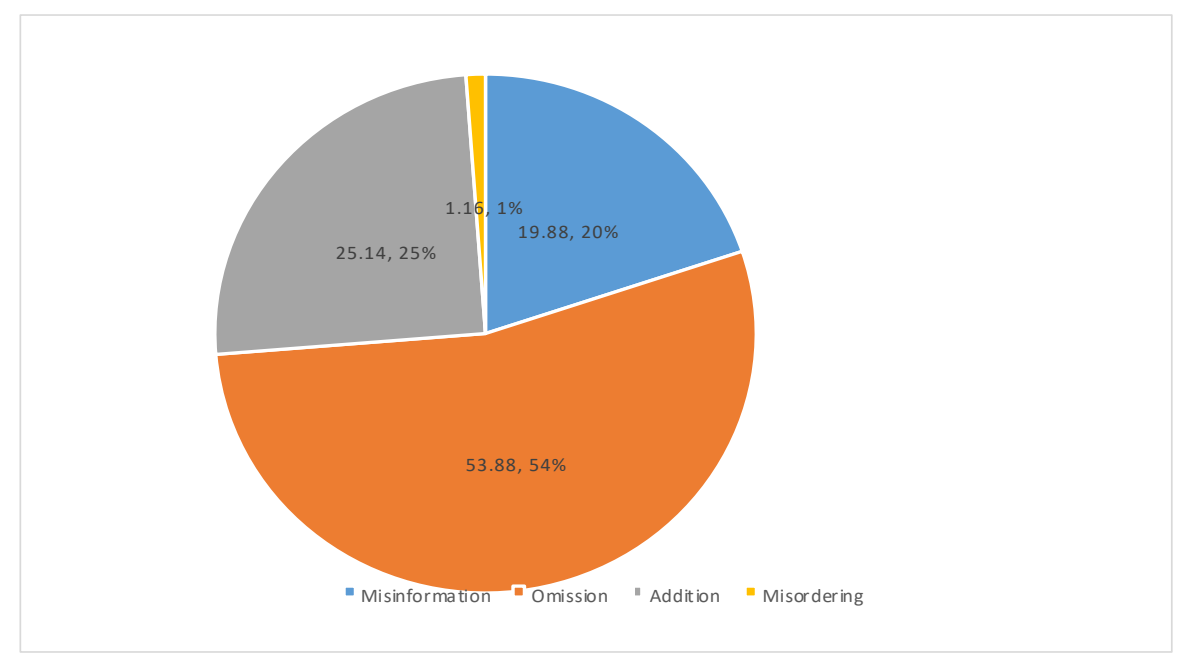

Figure 2 The Chart of the Error of the Use Passive Sentences of Students in Writing Recount Text.

\section{Conclusions}

Students make some errors in using active sentences in the students' writing recount text. Based on Dulay's Strategy Taxonomy, there are four types of error: omission, addition, misinformation, misordering. The results of the students' errors are the total error in using active sentences are 171 errors that consist of 34 errors or $19,88 \%$ error of misinformation, 92 errors or 53,88\% error of omission, 43 errors or $25,14 \%$ error of addition, two errors or 1,66\% error of misordering. According to the data above, the lowest error in using active sentences is in misordering two errors, or $1,66 \%$. Then, the highest errors in using active sentences are in omission 92 errors or 53,88\%. It means that almost all students have errors in omission. The error is mainly because the students forgot and were confused when using the active sentence in writing recount text. They are still confused in arranging the sentences and sometimes forget to change the present into a past participle, still lacking vocabularies.

According to the sample analysis, students have some errors in using passive sentences on students' writing recount text. Based on Dulay's Strategy Taxonomy, there are four types of error: omission, addition, misinformation, misordering. The results of the students' errors are the total error in using passive sentences are 17 errors that consist of 5 errors or $29,41 \%$ error of misinformation, six errors or $35,29 \%$ error of omission, six errors or $35,29 \%$ error of addition, 0 errors or $0 \%$ error of misordering. According to the data above, the lowest error in using passive sentences is in misordering 0 errors or $0 \%$. Then, the highest errors in using active sentences are omission and addition six errors or $35,29 \%$. It means that almost all students have errors in omission and addition. The error is mainly because the students forgot and were confused when using passive sentences in writing recount text. They are still confused in arranging the sentences because not familiar with the passive sentences, and the students still lack vocabularies and the grammatical of passive sentences.

The results of this research are theoretically and practically expected to give a contribution to educational institutions. Theoretically, the active and the passive sentences of the text both the same of the identifying avoided the plain of the sentences of the writing text. (to increase and make the writing of the sentences, the text becomes faster must the writer's ability to be accustomed and make it in a habit in the daily life of the writing in the text). When writing the recount text, the students use the active sentences and passive sentences by the verb, adjective, adverb to write the text. 


\section{INFERENCE: Journal of English Language Teaching}

Vol. 4, No. 1, April - July 2021

p-ISSN: 2615-8671

e-ISSN: 2615-868X

Practically, to make a quick test to help you and make you understand the difference between the active and the passive sentences, it is a must analyze the sentences and paragraph carefully of the active and passive sentences (to implement the analyzing of the active and passive sentences have to be careful of every word until to correct sentences and paragraph of the text) because the text must analyze the active and the passive sentences on students' writing recount text to make the sentences into good and correct sentences of the experience of the writing recount text of the students. It also makes them understand how to use the active and the passive sentences.

\section{References}

Ansel, A. (2000). Free English Grammar. Seyfihoca: www. Seyfihoca.com.

Azar, B. S. (2003). Fundamentals of English Grammar (Third Edition). New York: Pearson Edition.

Burhan Nurgiyantoro. (2016). Penilaian Pembelajaran Bahasa (Second Edition)

Daniel Jones. (1977). English Pronunciation Dictionary (Fourteenth Edition).

David Paul. (2003). Teaching English to Children in Asia. Longman.

David Peaty. (1983). Working English with Idioms.

Dendy Sugono. (2014). Peran dan kekuatan Bahasa Indonesia Dalam Industri Kreatif kebahasaan.

Dendy Sugono. (2019). Sintaksis Bahasa Indonesia Pelepasan Subjek.

Ellis, R. (2002). Learning to learn English. Cambridge University Press.

Frankel, R, Jack. Wallen, E. Norman and Hyun, H. Helen. (2012). How to design and Evaluate Research in Education. New York: Mc. Graw. Hill.

Glyn S. Hughes. (1989). A handbook of Classroom English. Oxford University.

H. Douglas Brown. (2000). Teaching by Principles an Interlanguage Approach to Language Pedagogy (Second Edition). Longman.

I.S.P Nation and John Macalister. (2010). Language Curriculum Design.

Jeremy Harmer. (2004). How to teach writing. Pearson Longman.

Jeremy Harmer. (2008). How to teach writing. Pearson Longman.

Kenneth L. Pike and Evelyn G. Pike. (1977). Grammatical Analysis.

M.J Lado. (1986). Mastering English Grammar and Idioms.

Marianne Celce- Murcia \& Diane Larsen - Freeman. (1999) The Grammar Book (Second Edition).

Nancy H. Hornberger \& Sandra Lee McKay. (2010). Sociolinguistics and Language Education. British Library.

Parrot Martin. (2004). Grammar for English Language Teachers (Second Edition). Cambridge University.

Raymond Murphy. (1994). English Grammar In Use (Second Edition).

Sugiyono. (2012). Metode penelitian Kuantitatif, kualitatif, dan R\&D. Bandung: Alfabeta.

Taylor, Gordon. (2009). A Student's Writing Guide. Cambridge University Press.

Walker, Elaine \& Elsworth, Steve. (2000). Grammar Practice. Edinburgh: Longman.

Williman, Nicholas. (2011). Research Method. New York: Routledge. 